\title{
FAKTOR RESIKO KEJADIAN KUSTA PADA ANAK USIA 5 - 14 TAHUN DI KOTA SORONG PAPUA BARAT
}

\author{
RISK FACTORS OF LOSSES ON CHILDREN AGES 5-14 YEARS IN WEST PAPUA SORONG CITY
}

Yehud Maryen, Jansen Parlaungan

Poltekkes Kemenkes Sorong

\section{ABSTRAK}

Kusta adalah salah satu penyakit menular yang masih merupakan masalah nasional kesehatan masyarakat, dimana beberapa daerah di Indonesia prevalensi rate masih tinggi dan permasalahan yang ditimbulkan sangat komplek. Angka proporsi anak usia kurang dari 14 tahun yang menderita kusta merupakan salah satu indikator keberhasilan program pemberantasan kusta, di mana angka ini dapat digunakan untuk melihat keadaan penularan saat ini dan memperkirakan kebutuhan obat. Tujuan Penelitian adalah untuk mengetahui faktor yang berisiko dengan kejadian kusta pada anak usia 5 - 14 tahun di Kota Sorong Provinsi Papua Barat. Penelitian ini bertujuan untuk mengetahui faktor yang berisiko dengan kejadian kusta pada anak usia 5 - 14 tahun di Kota Sorong Provinsi Papua Barat. Populasi dalam penelitian ini Populasi penelitian ini terdiri dari populasi aktual dan populasi target atau sasaran. Populasi aktual adalah seluruh penderita kusta yang telah atau sedang menjalani pengobatan kusta sekurang-kurangnya 12 bulan dan tercatat di Dinas Kesehatan Kota Sorong pada periode Januari sampai Desember 2016. Sampel pada penelitian ini berjumlah 54 responden. Instrument penelitian menggunakan kuisioner. Tehnik pengumpulan data yaitu data primer dan sekunder. Analisa Data secara analisa univariat dan bivariat. Data diolah dengan menggunakan Program SPSS versi 16.

Hasil penelitian menunjukkan bahwa Hasil uji chi-square diperoleh nilai $p(1,000)>\operatorname{sig}(0,05)$ sehingga Ho diterima. Hal ini berarti dapat diketahui bahwa tidak ada hubungan antara jenis kelamin dengan kejadian kusta. Nilai odd ratio $(\mathrm{OR})=1,176(>1=$ bersifat resiko $)$ hal ini berarti bahwa responden dengan jenis kelamin laki-laki memiliki resiko 1,176 kali untuk terkena penyakit kusta dibandingkan dengan responden berjenis kelamin perempuan. Hasil uji chi-square diperoleh nilai $p(0,788)>\operatorname{sig}(0,05)$ sehingga Ho diterima. Hal ini berarti dapat diketahui bahwa tidak ada hubungan antara umur dengan kejadian kusta. Nilai odd ratio $(\mathrm{OR})=1,375(>1$ = bersifat resiko) hal ini berarti bahwa responden dengan umur 5-9 tahun memiliki resiko 1,375 kali untuk terkena penyakit kusta dibandingkan dengan responden umur 10-14 tahun. Hasil uji chi-square diperoleh nilai $p(0,569)>\operatorname{sig}(0,05)$ sehingga Ho diterima. Hal ini berarti dapat diketahui bahwa tidak ada hubungan antara pendidikan orang tua dengan kejadian kusta. Nilai odd ratio $(\mathrm{OR})=1,633(>1=$ bersifat resiko $)$ hal ini berarti bahwa responden dengan pendidikan orang tua SD,SMP memiliki resiko 1,633 kali untuk terkena penyakit kusta dibandingkan dengan responden dengan pendidikan orang tua SMA,PT. Hasil uji chi-square diperoleh nilai $p(0,000)<\operatorname{sig}(0,05)$ sehingga Ho ditolak. Hal ini berarti dapat diketahui bahwa ada hubungan antara ekonomi orang tua dengan kejadian kusta. Nilai odd ratio $(\mathrm{OR})=13,600(>1=$ bersifat resiko) hal ini berarti bahwa responden dengan status ekonomi orang tua < UMP Sorong memiliki resiko 13,600 kali untuk terkena penyakit kusta dibandingkan dengan responden dengan status ekonomi orang tua $\geq$ UMP Sorong. Hasil uji chi-square diperoleh nilai $p(0,766)>\operatorname{sig}(0,05)$ sehingga Ho diterima. Hal ini berarti dapat diketahui bahwa tidak ada hubungan antara pekerjaan orang tua dengan kejadian kusta. Nilai odd ratio $(\mathrm{OR})=0,700(<1=$ bersifat protektif) hal ini berarti pekerjaan orang tua tidak terlalu beresiko dengan kejadian kusta. Hasil uji chi-square diperoleh nilai $p(0,136)>\operatorname{sig}(0,05)$ sehingga Ho diterima. Hal ini berarti dapat diketahui bahwa tidak ada hubungan antara personal hygene dengan kejadian kusta. Nilai odd ratio $(\mathrm{OR})=3,025$ ( $>1$ = bersifat resiko) hal ini berarti bahwa responden dengan personal hygiene buruk memiliki resiko 3,025 kali untuk terkena penyakit kusta dibandingkan dengan responden dengan personal hygiene baik. Hasil uji chi-square diperoleh nilai $p(0,000)<\operatorname{sig}(0,05)$ sehingga Ho ditolak. Hal ini berarti dapat diketahui bahwa ada hubungan antara ada riwayat kontak dengan kejadian kusta. Nilai odd ratio $(\mathrm{OR})=35,714$ ( $>1=$ bersifat resiko) hal ini berarti bahwa responden dengan ada riwayat kontak serumah memiliki resiko 35,714 kali untuk terkena penyakit kusta dibandingkan dengan responden dengan tidak ada riwayat kontak serumah

Kesimpulan bahwa ada resiko antara ekonomi orang tua dan ada riwayat kontak serumah dengan kejadian kusta diwilayah kota sorong pada anak umur 5 - 14 tahun, dan tidak ada resiko antara jenis kelamin, umur, pendidikan orang tua, pekerjaan orang tua, personal hygene dengan kejadian kusta diwilayah kota sorong pada anak umur 5 - 14 tahun

Kata Kunci : Kusta, Anak

Daftar Pustaka $\quad$ : 2000 - 2016

\section{ABSTRACT}

Leprosy is one of the contagious diseases that is still a national public health problem, where some areas in Indonesia the prevalence rate is still high and the problems posed are very complex. The proportion of children under 14 years old suffering from leprosy is an indicator of the success of the leprosy eradication program, where this figure can be used to look at the current state of contagion and estimate the need for the drug. The aim of this research is to know the risk factors with the incidence of leprosy in children aged 5 - 14 years in Sorong City West Papua Province.

This study aims to determine the factors that are at risk with the incidence of leprosy in children aged 5-14 years in Sorong City West Papua Province. Population in this study The population of this study consists of actual population and target population or target. The actual population is all leprosy patients who have or are undergoing leprosy treatment at least 12 months and recorded in Sorong City Health Office in the period January to December 2016. The sample in this study amounted to 54 respondents. The research instrument used questionnaires. Data collection techniques are primary and secondary data. Univariate and bivariate analysis. Data is processed by using SPSS Program version 16.

The results showed that chi-square test results obtained $\mathrm{p}$ value $(1,000)>\operatorname{sig}(0,05)$ so that Ho accepted. This means it can be seen that there is no relationship between sex with the incidence of leprosy. The odd ratio $(\mathrm{OR})=1.176(>1=$ risk) means that respondents with male sex have a risk of 1,176 times for leprosy compared with female respondents. Chi-square test results obtained $p$ value $(0.788)>\operatorname{sig}(0.05)$ so Ho is accepted. This means that it can be seen that there is no relationship between age and the incidence of leprosy. The odd ratio $(\mathrm{OR})=1.375(>1=$ risk) means that respondents with age 5-9 years have a risk of 1,375 times for leprosy compared with respondents aged 10-14 years. The result of chi-square test obtained $\mathrm{p}$ value $(0,569)>\operatorname{sig}(0,05)$ so Ho is accepted. This means that it can be seen that there is no relationship between parental education and leprosy events. The odd ratio $(\mathrm{OR})=1.633(>1=$ risk) means that respondents with primary, junior secondary education have a risk of 1,633 times for leprosy compared with respondents with high school parents education, PT. Chi-square test results obtained $\mathrm{p}$ value $(0,000)<\operatorname{sig}(0.05)$ so that Ho is rejected. This means it can be seen that there is a relationship between the economy of the elderly with the incidence of leprosy. The odd ratio $(\mathrm{OR})=13,600(>1=$ risk) means that respondents with unjust economic status <UMP Sorong have a risk of 13,600 times for leprosy compared with respondents with > UMP Sorong economic status. Chi-square test results obtained p value $(0.766)>\operatorname{sig}(0.05)$ so Ho is accepted. This means it can be seen that there is no relationship between the work of parents with the incidence of leprosy. The odd ratio $(\mathrm{OR})=0.700(<1=$ protective $)$ means that the parent's work is not too risky with leprosy. Chi-square test results obtained $\mathrm{p}$ value $(0.136)>\operatorname{sig}(0.05)$ so Ho is accepted. This means that it can be seen that there is no relationship between personal hygene and leprosy. The odd ratio $(\mathrm{OR})=3.025(>1=$ risk) means that respondents with poor personal hygiene have a risk of 3,025 times for leprosy compared to respondents with good hygiene. Chi-square test results obtained p value $(0,000)<\operatorname{sig}(0.05)$ so that Ho is rejected. This means that it can be seen that there is a relationship between a history of contact with the incidence of leprosy. The odds ratio $(\mathrm{OR})=35.714(>1=$ risk) means that respondents with a household contact history have a 35.714 times risk for leprosy compared with respondents with no household contact.

Conclusion that there is a risk between parent economies and there is a history of home contact with leprosy in the urban area of sorong in children aged 5-14 years, and there is no risk between sex, age, parent education, parent occupation, personal hygene with leprosy in the area of sorong city in children aged 5-14 years

Keywords : Leprosy, Child

References: 2000 - 2016 


\section{A. PENDAhuluan}

Kusta adalah salah satu penyakit menular yang masih merupakan masalah nasional kesehatan masyarakat, dimana beberapa daerah di Indonesia prevalensi rate masih tinggi dan permasalahan yang ditimbulkan sangat komplek. Kusta pada umumnya terdapat di negara-negara yang sedang berkembang sebagai akibat keterbatasan kemampuan negara itu dalam memberi pelayanan yang memadai dalam bidang kesehatan, pendidikan, kesejahteraan sosial dan ekonomi pada masyarakat ${ }^{1}$.

Kusta atau juga dikenal sebagai lepra atau Morbus Hansen merupakan penyakit menular yang disebabkan oleh Mycobacterium leprae. Penyakit ini masih menjadi masalah kesehatan di beberapa negara sedang berkembang, dan bila perkembangan penyakit ini tidak ditangani secara cermat dapat menyebabkan kecacatan bagi penderitanya yang berakibat terganggunya kualitas sumber daya manusia, sehingga akan menjadi halangan dalam memenuhi kebutuhan sosial ekonomi. Penyakit ini sangat ditakuti bukan karena menyebabkan kematian melainkan lebih banyak menyebabkan kecacatan yang permanen ${ }^{2}$.

Penyakit kusta merupakan penyakit kronis yang menyerang saraf tepi, kulit dan jaringan tubuh lainnya. Diagnosa penyakit kusta ditegakkan dengan ditemukannya tanda - tanda utama, yaitu : adanya lesi kulit yang mati rasa, penebalan saraf tepi dengan disertai gangguan fungsi saraf serta di temukannya bakteri tahan asam (BTA). Menurut Word Health Organizations (WHO), penyakit kusta diklasifikasikan menjadi 2 yaitu : tipe PB (pausi basiler) dan tipe MB (multi basiler) ${ }^{3}$.

Berdasarkan data WHO, jumlah kasus kusta di dunia sampai bulan Maret 2013 sebanyak 189.018 kasus, dengan jumlah kasus baru pada tahun 2012 sebanyak 232.857 kasus. Berdasarkan data resmi dari departemen kesehatan negara endemik, deteksi penyakit kusta yang dilakukan setiap tahun secara global menunjukkan penurunan kasus sejak tahun 2001, terjadi penurunan kasus hingga lebih dari 46\%. Pada tahun 2004 ditemukan sebanyak 407.791 kasus baru dan terus mengalami penurunan menjadi 228.474 kasus pada tahun 2010 dan sebanyak 219.075 pada tahun 2011. Proporsi insiden kusta di berbagai benua antara lain di benua Afrika, sebanyak $61,72 \%$ terdapat di Kongo dan sebanyak 99,21\% di Kenya. Di wilayah Amerika sebanyak 40,88\% terdapat di Brazil dan sebanyak $83.06 \%$ di Kuba.

Di Wilayah Asia Tenggara, ditemukan di Bangladesh sebanyak $42,33 \%$ dan di Indonesia sebanyak $80,96 \%$. Di wilayah Timur Mediterania terdapat $61,95 \%$ insiden kusta di Yaman dan sebanyak $88,38 \%$ di Mesir sedangkan di wilayah Pasifik Barat proporsinya berkisar antara $29,67 \%$ di Kiribati dan sebanyak $93.92 \%$ terdapat di Filipina. Kasus baru kusta di Indonesia pada tahun 2010 dilaporkan sebanyak 17.012 kasus, terdiri dari tipe Multi Basiler sebanyak 13.734 kasus 
dan tipe Pausi Basiler sebanyak 3.278 dengan Newly Case Detection Rate (NCDR) sebesar 7,22 per 100.000 penduduk. Jumlah kasus terdaftar sebanyak 20.329 kasus dengan prevalensi 0,86 per 10.000 penduduk $^{4}$.

Kusta tersebar diseluruh dunia dengan endemisitas yang berbeda-beda. World Health Organization (WHO) mencatat awal tahun 2011 dilaporkan prevalensi kusta di seluruh dunia sebesar 192.246 kasus dengan jumlah penderita kusta tertinggi yaitu di regional Asia Tenggara sebesar 113.750 kasus. Tiga negara teratas dengan jumlah kasus kusta terbanyak adalah India, Brazil dan Indonesia, dimana negara-negara tersebut termasuk dalam daerah endemik kusta ${ }^{5}$.

Kondisi ini cukup memprihatinkan karena kusta tidak hanya merupakan masalah kesehatan saja, tapi juga masalah sosial dan HAM. Penderita kusta mengalami stigma sosial, isolasi, dan kehilangan hakhaknya. Pasien yang telah sembuh dan keluarganya juga menderita trauma sosio-psikologis dan kemiskinan. Indonesia secara nasional telah mencapai tingkat eliminasi kusta pada tahun 2000 dengan menurunkan tingkat rata-rata penderita di bawah satu orang per 10.000 penduduk dengan poin 0,95 . Sebanyak 287.274 telah disembuhkan sejak tahun 1995 melalui program Multi Drug Treatment. Namun 12 provinsi di Indonesia masih memiliki tingkat penderita kusta di atas satu orang per 10.000 penduduk. Provinsi ini adalah NAD (1,51), Kalimantan Selatan (1,07),
Jawa Timur (1,67), Sulawesi Utara (2,57), Sulawesi Tengah $(1,17)$, Sulawesi Selatan (2,02), Sulawesi Tenggara (1,21), Gorontalo (3,62), NTT $(1,17)$, Maluku Utara $(9,51)$, Maluku $(3,47)$, dan Papua $(4,62)^{2}$.

Indikator lain yang digunakan pada penyakit kusta yaitu proporsi kusta MB dan proporsi penderita kusta pada anak (kurang dari 14 tahun) di antara penderita baru yang memperlihatkan sumber utama dan tingkat penularan di masyarakat. Proporsi kusta MB periode 2011-2015 relatif menunjukkan peningkatan yaitu dari $80,4 \%$ meningkat hingga 84,5\%. Provinsi dengan proporsi kusta MB tertinggi pada tahun 2015 yaitu Bengkulu, Kalimantan Tengah (100\%), Lampung $(94,34 \%)$ dan Gorontalo (91,03\%). Sedangkan proporsi kusta anak pada periode yang sama yaitu sekitar 10\%$12 \%$. Provinsi dengan proporsi kusta pada anak tertinggi yaitu Papua Barat $(30,82)$, Papua $(23,62 \%)$, dan Maluku Utara $(19,49 \%)^{6}$.

Berdasarkan status eliminasi, kusta dibagi menjadi 2 kelompok yaitu provinsi yang belum eliminasi dan provinsi yang sudah mencapai eliminasi. Provinsi yang belum mencapai eliminasi jika angka prevalensi > 1 per 10.000 penduduk, sedangkan provinsi yang sudah mencapai eliminasi jika angka prevalensi < 1 per 10.000 penduduk. Data Profil Kesehatan 2015 menyebutkan bahwa dari 34 provinsi, sebanyak 12 provinsi $(35,3 \%)$ termasuk dalam provinsi yang belum eliminasi. 
Sedangkan 22 provinsi lainnya $(64,7 \%)$ termasuk dalam provinsi yang sudah eliminasi. Seluruh provinsi di bagian timur Indonesia merupakan daerah yang belum mencapai eliminasi. Provinsi Aceh dan Banten di tahun 2013 angka prevalensinya $>1$ per 10.000 penduduk (belum eliminasi) namun di tahun 2014 dan 2015 kedua provinsi ini berhasil mencapai eliminasi ${ }^{6}$.

Angka proporsi anak usia kurang dari 14 tahun yang menderita kusta merupakan salah satu indikator keberhasilan program pemberantasan kusta, di mana angka ini dapat digunakan untuk melihat keadaan penularan saat ini dan memperkirakan kebutuhan obat. Berdasarkan permasalahan tersebut maka peneliti tertarik untuk mengetahui faktor risiko yang berhubungan dengan kejadian kusta pada anak usia 5 - 14 tahun di Kota Sorong Provinsi Papua Barat.

\section{B. METODE PENELITIAN}

Penelitian ini merupakan jenis observasional dengan rancangan studi kasus kontrol (Case control studi). Penelitian dimulai dengan identifikasi kasus dan bukan kasus (kontrol), kemudian diteliti faktor risiko secara retrospektif kemudian menganalisa perbandingan antara proporsi subyek yang terpapar dengan subyek tidak terpapar, kemudian dicari faktor risiko yang menyebabkan kejadian penyakit tersebut. Untuk mengetahui estimasi besarnya faktor risiko terhadap kejadian penyakit, ditentukan dengan menggunakan nilai Odds ratio (OR). 


\section{HASIL PENELITIAN}

1. Analisis Univariat

a. Karakteristik Responden Berdasarkan Jenis Kelamin

Tabel 4.1. Distribusi responden berdasarkan jenis kelamin

\begin{tabular}{|c|c|c|c|}
\hline No & Jenis Kelamin & Frekuensi & $\begin{array}{c}\text { Presentase } \\
(\%)\end{array}$ \\
\hline 1 & Laki-Laki & 35 & 64,8 \\
\hline 2 & Perempuan & 19 & 35,2 \\
\hline No & Umur & Frekuensi & $\begin{array}{c}\text { Presentase } \\
(\%)\end{array}$ \\
\hline 1 & $5-9$ Tahun & 20 & 37,0 \\
\hline 2 & $10-14$ tahun & 34 & 63,0 \\
\hline No & Pendidikan & Frekuensi & $\begin{array}{c}\text { Presentase } \\
(\%)\end{array}$ \\
\hline 1 & SD,SMP & 35 & 64,8 \\
\hline 2 & SMA,PT & 19 & 35,2 \\
\hline No & Ekonomi & Frekuensi & $\begin{array}{c}\text { Presentase } \\
(\%)\end{array}$ \\
\hline 1 & $<$ UMP Sorong & 34 & 63,0 \\
\hline 2 & $\geq$ UMP Sorong & 20 & 37,0 \\
\hline No & Pekerjaan & Frekuensi & $\begin{array}{c}\text { Presentase } \\
(\%)\end{array}$ \\
\hline 1 & $\geq 8$ jam sehari & 38 & 70,4 \\
\hline 2 & $<8$ jam sehari & 16 & 29,6 \\
\hline No & Personal Hygene & Frekuensi & $\begin{array}{c}\text { Presentase } \\
(\%)\end{array}$ \\
\hline 1 & Buruk & 38 & 70,4 \\
\hline 2 & Baik & 16 & 29,6 \\
\hline No & Kontak Serumah & Frekuensi & $\begin{array}{c}\text { Presentase } \\
(\%)\end{array}$ \\
\hline 1 & Ada Kontak Serumah & 32 & 59,3 \\
\hline 2 & Tidak Ada Kontak Serumah & 22 & 40,7 \\
\hline No & Kejadian Kusta & Frekuensi & $\begin{array}{c}\text { Presentase } \\
(\%)\end{array}$ \\
\hline 1 & Kasus & 27 & 50,0 \\
\hline 2 & Kontrol & 27 & 50,0 \\
\hline & Jumlah & 54 & 100 \\
\hline
\end{tabular}


Berdasarkan tabel 4.1 dapat diketahui distribusi frekuensi responden berdasarkan jenis kelamin dari 54 responden paling banyak laki-laki yaitu 35 orang $(64,8 \%)$ sedangkan perempuan yaitu 19 orang $(35,2 \%)$. Berdasarkan tabel 4.2 dapat diketahui distribusi frekuensi responden berdasarkan umur dari 54 responden paling banyak umur 10 14 Tahun yaitu 34 orang $(63,0 \%)$ sedangkan umur 5-9 tahun yaitu 20 orang $(37,0 \%)$. Berdasarkan tabel 4.3 dapat diketahui distribusi frekuensi responden berdasarkan pendidikan orang tua dari 54 responden paling banyak SD,SMP yaitu 35 orang $(64,8 \%)$ sedangkan SMA,PT yaitu 19 orang $(35,2 \%)$. Berdasarkan tabel 4.4 dapat diketahui distribusi frekuensi responden berdasarkan ekonomi orang tua dari 54 responden paling banyak < UMP Sorong yaitu 34 orang $(63,0 \%)$ sedangkan $>$ UMP Sorong yaitu 20 orang $(37,0 \%)$. Berdasarkan tabel 4.5 dapat diketahui distribusi frekuensi responden berdasarkan pekerjaan orang tua dari 54 responden paling banyak $>8$ jam sehari yaitu 38 orang $(70,4 \%)$ sedangkan $<8$ jam sehari yaitu 16 orang $(29,6 \%)$. Berdasarkan tabel 4.6 dapat diketahui distribusi frekuensi responden berdasarkan personal hygene dari 54 responden paling banyak buruk yaitu 38 orang $(70,4 \%)$ sedangkan baik yaitu 16 orang $(29,6 \%)$. Berdasarkan tabel 4.7 dapat diketahui distribusi frekuensi responden berdasarkan kontak serumah dari 54 responden paling banyak Ada Kontak Serumah yaitu 32 orang $(59,3 \%)$ sedangkan Tidak Ada Kontak Serumah yaitu 22 orang (40,7\%). Berdasarkan tabel 4.8 dapat diketahui distribusi frekuensi responden berdasarkan kejadian kusta dari 54 responden kelompok kasus yaitu 27 orang $(50,0 \%)$ sedangkan kelompok kontrol yaitu 27 orang $(50,0 \%)$.

\section{Analisa Bivariat}

\section{a. Hubungan antara jenis kelamin dengan kejadian kusta}

Hasil uji chi square dari hubungan antara jenis kelamin dengan kejadian kusta pada kelompok kasus maupun control didapatkan hasil sebagai berikut :

Tabel 4.9. Tabulasi silang jenis kelamin dengan Kejadian Kusta

\begin{tabular}{|l|c|c|c|c|c|c|c|c|}
\hline \multirow{2}{*}{ Jenis Kelamin } & \multicolumn{6}{|c|}{ Kejadian Kusta } & \multirow{2}{*}{ P Value } & \multirow{2}{*}{ OR } \\
\cline { 2 - 8 } & $\begin{array}{c}\text { N } \\
\text { Kasus }\end{array}$ & $\mathbf{\%}$ & $\begin{array}{c}\text { N } \\
\text { Kontrol }\end{array}$ & $\mathbf{\%}$ & N Total & \% & & \\
\hline Laki-Laki & 18 & 51,4 & 17 & 48,6 & 35 & 100 & \multirow{2}{*}{1,000} & \multirow{2}{*}{1,176} \\
\hline Perempuan & 9 & 47,4 & 10 & 52,6 & 19 & 100 & \\
\hline Jumlah & 27 & 50 & 27 & 50 & 54 & 100 & & \\
\hline
\end{tabular}

Berdasarkan tabel 4.9. dapat diperoleh informasi bahwa responden dengan jenis kelamin laki-laki lebih besar pada kelompok kasus 18 orang $(51,4 \%)$ dibandingkan 
dengan kelompok control 17 orang $(48,6 \%)$ sedangkan responden dengan jenis kelamin perempuan lebih besar pada kelompok kontrol 10 orang $(52,6 \%)$ dibandingkan dengan kelompok kasus 9 orang $(47,4 \%)$.

Hasil uji chi-square diperoleh nilai $p(1,000)>\operatorname{sig}(0,05)$ sehingga Ho diterima. Hal ini berarti dapat diketahui bahwa tidak ada hubungan antara jenis kelamin dengan kejadian kusta. Nilai odd ratio $(\mathrm{OR})=1,176$ ( $>1=$ bersifat resiko) hal ini berarti bahwa responden dengan jenis kelamin laki-laki memiliki resiko 1,176 kali untuk terkena penyakit kusta dibandingkan dengan responden berjenis kelamin perempuan.

\section{b. Hubungan antara umur dengan kejadian kusta}

Hasil uji chi square dari hubungan antara umur dengan kejadian kusta pada kelompok kasus maupun control didapatkan hasil sebagai berikut :

Tabel 4.10. Tabulasi silang umur dengan Kejadian Kusta

\begin{tabular}{|c|c|c|c|c|c|c|c|c|}
\hline \multirow[t]{2}{*}{ Umur } & \multicolumn{6}{|c|}{ Kejadian Kusta } & \multirow[t]{2}{*}{ P Value } & \multirow[t]{2}{*}{ OR } \\
\hline & $\begin{array}{c}\mathbf{N} \\
\text { Kasus }\end{array}$ & $\%$ & $\begin{array}{c}\mathrm{N} \\
\text { Kontrol }\end{array}$ & $\%$ & N Total & $\%$ & & \\
\hline 5-9 Tahun & 11 & 55,0 & 9 & 45,0 & 20 & 100 & \multirow{3}{*}{0,778} & \multirow{3}{*}{1,375} \\
\hline 10-14 Tahun & 16 & 47,1 & 18 & 52,9 & 34 & 100 & & \\
\hline Jumlah & 27 & 50 & 27 & 50 & 54 & 100 & & \\
\hline
\end{tabular}

Berdasarkan tabel 4.10. dapat diperoleh informasi bahwa responden dengan umur 5 - 9 tahun lebih besar pada kelompok kasus 11 orang $(55,0 \%)$ dibandingkan dengan kelompok kontrol 9 orang $(45,0 \%)$ sedangkan responden dengan umur 10 - 14 tahun lebih besar pada kelompok kontrol 18 orang $(52,9 \%)$ dibandingkan dengan kelompok kasus 16 orang $(47,1 \%)$.

Hasil uji chi-square diperoleh nilai $p(0,788)>\operatorname{sig}(0,05)$ sehingga Ho diterima. Hal ini berarti dapat diketahui bahwa tidak ada hubungan antara umur dengan kejadian kusta. Nilai odd ratio $(\mathrm{OR})=1,375$ ( $>1=$ bersifat resiko) hal ini berarti bahwa responden dengan umur 5-9 tahun memiliki resiko 1,375 kali untuk terkena penyakit kusta dibandingkan dengan responden umur 10-14 tahun.

\section{c. Hubungan antara pendidikan orang tua dengan kejadian kusta}

Hasil uji chi square dari hubungan antara pendidikan orang tua dengan kejadian kusta pada kelompok kasus maupun control didapatkan hasil sebagai berikut :

Tabel 4.11. Tabulasi silang pendidikan orang tua dengan

Kejadian Kusta

\begin{tabular}{|l|c|c|c|c|c|c|c|c|}
\hline \multirow{2}{*}{ Pendidikan orang tua } & \multicolumn{9}{|c|}{ Kejadian Kusta } & \multirow{2}{*}{ P Value } & \multirow{2}{*}{ OR } \\
\cline { 2 - 8 } & $\begin{array}{c}\mathbf{N} \\
\text { Kasus }\end{array}$ & $\mathbf{\%}$ & $\begin{array}{c}\mathbf{N} \\
\text { Kontrol }\end{array}$ & $\boldsymbol{\%}$ & $\mathbf{N}$ Total & $\%$ & & \\
\hline SD,SMP & 19 & 54,3 & 16 & 45,7 & 35 & 100 & \multirow{2}{*}{0,569} & \multirow{2}{*}{1,633} \\
\hline SMA,PT & 8 & 42,1 & 11 & 57,9 & 19 & 100 & \\
\hline Jumlah & 27 & 50 & 27 & 50 & 54 & 100 & & \\
\hline
\end{tabular}


Berdasarkan tabel 4.11. dapat diperoleh informasi bahwa responden dengan pendidikan orang tua SD,SMP lebih besar pada kelompok kasus 19 orang $(54,3 \%)$ dibandingkan dengan kelompok kontrol 16 orang $(45,7 \%)$ sedangkan responden dengan pendidikan orang tua SMA,PT lebih besar pada kelompok kontrol 11 orang $(57,9 \%)$ dibandingkan dengan kelompok kasus 8 orang $(42,1 \%)$.

Hasil uji chi-square diperoleh nilai $p(0,569)>\operatorname{sig}(0,05)$ sehingga Ho diterima. Hal ini berarti dapat diketahui bahwa tidak ada hubungan antara pendidikan orang tua dengan kejadian kusta. Nilai odd ratio $(\mathrm{OR})=1,633(>1=$ bersifat resiko) hal ini berarti bahwa responden dengan pendidikan orang tua SD,SMP memiliki resiko 1,633 kali untuk terkena penyakit kusta dibandingkan dengan responden dengan pendidikan orang tua SMA,PT.

\section{d. Hubungan antara ekonomi orang tua dengan kejadian kusta}

Hasil uji chi square dari hubungan antara ekonomi orang tua dengan kejadian kusta pada kelompok kasus maupun control didapatkan hasil sebagai berikut :

Tabel 4.12. Tabulasi silang ekonomi orang tua dengan Kejadian Kusta

\begin{tabular}{|c|c|c|c|c|c|c|c|c|}
\hline \multirow[t]{2}{*}{ Ekonomi orang tua } & \multicolumn{6}{|c|}{ Kejadian Kusta } & \multirow[t]{2}{*}{ P Value } & \multirow[t]{2}{*}{ OR } \\
\hline & $\begin{array}{c}\mathbf{N} \\
\text { Kasus }\end{array}$ & $\%$ & $\begin{array}{c}\mathbf{N} \\
\text { Kontrol }\end{array}$ & $\%$ & N Total & $\%$ & & \\
\hline$<$ UMP Sorong & 24 & 70,6 & 10 & 29,4 & 34 & 100 & \multirow{3}{*}{0,000} & \multirow{3}{*}{13,600} \\
\hline$\geq$ UMP Sorong & 3 & 15,0 & 17 & 85,0 & 20 & 100 & & \\
\hline Jumlah & 27 & 50 & 27 & 50 & 54 & 100 & & \\
\hline
\end{tabular}

Berdasarkan tabel 4.12. dapat diperoleh informasi bahwa responden dengan ekonomi orang tua < UMP Sorong lebih besar pada kelompok kasus 24 orang $(70,6 \%)$ dibandingkan dengan kelompok kontrol 10 orang $(29,4 \%)$ sedangkan responden dengan ekonomi orang tua > UMP Sorong lebih besar pada kelompok kontrol 17 orang $(85,0 \%)$ dibandingkan dengan kelompok kasus 3 orang $(15,0 \%)$.

Hasil uji chi-square diperoleh nilai $p(0,000)<$ sig $(0,05)$ sehingga Ho ditolak. Hal ini berarti dapat diketahui bahwa ada hubungan antara ekonomi orang tua dengan kejadian kusta. Nilai odd ratio $(\mathrm{OR})=13,600(>1=$ bersifat resiko) hal ini berarti bahwa responden dengan status ekonomi orang tua < UMP Sorong memiliki resiko 13,600 kali untuk terkena penyakit kusta dibandingkan dengan responden dengan status ekonomi orang tua $\geq$ UMP Sorong. 


\section{e. Hubungan antara pekerjaan orang tua dengan kejadian kusta}

Hasil uji chi square dari hubungan antara pekerjaan orang tua dengan kejadian kusta pada kelompok kasus maupun control didapatkan hasil sebagai berikut :

Tabel 4.13. Tabulasi silang pekerjaan orang tua dengan Kejadian Kusta

\begin{tabular}{|c|c|c|c|c|c|c|c|c|}
\hline \multirow[t]{2}{*}{ Pekerjaan orang tua } & \multicolumn{6}{|c|}{ Kejadian Kusta } & \multirow[t]{2}{*}{ P Value } & \multirow[t]{2}{*}{$\mathbf{O R}$} \\
\hline & $\begin{array}{c}\mathbf{N} \\
\text { Kasus } \\
\end{array}$ & $\%$ & $\begin{array}{c}\mathrm{N} \\
\text { Kontrol }\end{array}$ & $\%$ & N Total & $\%$ & & \\
\hline$\geq 8$ Jam sehari & 18 & 47,4 & 20 & 52,6 & 38 & 100 & \multirow{3}{*}{0,766} & \multirow{3}{*}{0,700} \\
\hline$<8$ jam sehari & 9 & 56,2 & 7 & 43,8 & 16 & 100 & & \\
\hline Jumlah & 27 & 50 & 27 & 50 & 54 & 100 & & \\
\hline
\end{tabular}

Berdasarkan tabel 4.13. dapat diperoleh informasi bahwa responden dengan pekerjaan orang tua $>8$ jam sehari lebih besar pada kelompok kontrol 20 orang $(52,6 \%)$ dibandingkan dengan kelompok kasus 18 orang $(47,4 \%)$ sedangkan responden dengan pekerjaan orang tua $<8$ jam sehari lebih besar pada kelompok kasus 9 orang $(56,2 \%)$ dibandingkan dengan kelompok kontrol 7 orang $(43,8 \%)$.

Hasil uji chi-square diperoleh nilai $p(0,766)>$ sig $(0,05)$ sehingga Ho diterima. Hal ini berarti dapat diketahui bahwa tidak ada hubungan antara pekerjaan orang tua dengan kejadian kusta. Nilai odd ratio $(\mathrm{OR})=0,700(<1=$ bersifat protektif $)$ hal ini berarti pekerjaan orang tua tidak terlalu beresiko dengan kejadian kusta

\section{f. Hubungan antara personal hygene dengan kejadian kusta}

Hasil uji chi square dari hubungan antara personal hygene dengan kejadian kusta pada kelompok kasus maupun control didapatkan hasil sebagai berikut :

Tabel 4.14. Tabulasi silang personal hygene dengan Kejadian Kusta

\begin{tabular}{|c|c|c|c|c|c|c|c|c|}
\hline \multirow[t]{2}{*}{ Personal hygene } & \multicolumn{6}{|c|}{ Kejadian Kusta } & \multirow[t]{2}{*}{ P Value } & \multirow[t]{2}{*}{ OR } \\
\hline & $\begin{array}{c}\mathbf{N} \\
\text { Kasus }\end{array}$ & $\%$ & $\begin{array}{c}\mathbf{N} \\
\text { Kontrol }\end{array}$ & $\%$ & N Total & $\%$ & & \\
\hline Buruk & 22 & 57,9 & 16 & 42,1 & 38 & 100 & \multirow{3}{*}{0,136} & \multirow{3}{*}{3,025} \\
\hline Baik & 5 & 31,2 & 11 & 68,8 & 16 & 100 & & \\
\hline Jumlah & 27 & 50 & 27 & 50 & 54 & 100 & & \\
\hline
\end{tabular}

Berdasarkan tabel 4.14. dapat diperoleh informasi bahwa responden dengan personal hygene buruk lebih besar pada kelompok kasus 22 orang $(57,9 \%)$ dibandingkan dengan kelompok control 16 orang $(42,1 \%)$ sedangkan responden dengan personal hygene baik lebih besar pada kelompok kontrol 11 orang $(68,8 \%)$ dibandingkan dengan kelompok kasus 5 orang $(31,2 \%)$.

Hasil uji chi-square diperoleh nilai $p(0,136)>\operatorname{sig}(0,05)$ sehingga Ho diterima. Hal ini berarti dapat diketahui bahwa tidak ada hubungan antara personal hygene dengan kejadian kusta. Nilai odd ratio $(\mathrm{OR})=3,025$ ( $>1=$ bersifat resiko) hal ini berarti bahwa responden dengan personal hygiene buruk memiliki resiko 3,025 kali untuk terkena penyakit kusta dibandingkan dengan responden dengan personal hygiene baik. 


\section{g. Hubungan antara kontak serumah dengan kejadian kusta}

Hasil uji chi square dari hubungan antara kontak serumah dengan kejadian kusta pada kelompok kasus maupun control didapatkan hasil sebagai berikut :

Tabel 4.15. Tabulasi silang kontak serumah dengan Kejadian Kusta

\begin{tabular}{|c|c|c|c|c|c|c|c|c|}
\hline \multirow[t]{2}{*}{ Kontak serumah } & \multicolumn{6}{|c|}{ Kejadian Kusta } & \multirow[t]{2}{*}{ P Value } & \multirow[t]{2}{*}{ OR } \\
\hline & $\begin{array}{c}\mathbf{N} \\
\text { Kasus }\end{array}$ & $\%$ & $\begin{array}{c}\mathrm{N} \\
\text { Kontrol }\end{array}$ & $\%$ & N Total & $\%$ & & \\
\hline Ada riwat kontak & 25 & 78,1 & 7 & 21,9 & 32 & 100 & \multirow{3}{*}{0,000} & \multirow{3}{*}{35,714} \\
\hline $\begin{array}{l}\text { Tidak ada riwayat } \\
\text { kontak }\end{array}$ & 2 & 9,1 & 20 & 90,9 & 22 & 100 & & \\
\hline Jumlah & 27 & 50 & 27 & 50 & 54 & 100 & & \\
\hline
\end{tabular}

Berdasarkan tabel 4.15. dapat diperoleh informasi bahwa responden dengan ada riwayat kontak lebih besar pada kelompok kasus 25 orang $(78,1 \%)$ dibandingkan dengan kelompok control 7 orang $(21,9 \%)$ sedangkan responden dengan tidak ada riwayat kontak lebih besar pada kelompok kontrol 20 orang $(90,9 \%)$ dibandingkan dengan kelompok kasus 2 orang $(9,1 \%)$.

Hasil uji chi-square diperoleh nilai $p(0,000)<\operatorname{sig}(0,05)$ sehingga Ho ditolak. Hal ini berarti dapat diketahui bahwa ada hubungan antara ada riwayat kontak dengan kejadian kusta. Nilai odd ratio $(\mathrm{OR})=35,714(>1=$ bersifat resiko) hal ini berarti bahwa responden dengan ada riwayat kontak serumah memiliki resiko 35,714 kali untuk terkena penyakit kusta dibandingkan dengan responden dengan tidak ada riwayat kontak serumah.

\section{Analisis Chi-Square dan Korelasi Spearmen}

Berdasarkan hasil penelitian yang dilakukan diperoleh hasil analisis bivariat dengan menggunakan uji chi-square dapat diketahui sebagai berikut :

Tabel 4.16. Hasil Analisis Bivariat dengan uji Chi-Square

\begin{tabular}{|l|l|c|c|c|}
\hline No & \multicolumn{1}{|c|}{ Variabel Bebas } & P Value & OR & Keterangan \\
\hline 1 & Jenis Kelamin & 1,000 & 1,176 & Tidak Beresiko \\
2 & Umur & 0,778 & 1,357 & Tidak Beresiko \\
3 & Pendidikan orang Tua & 0,569 & 1,633 & Tidak Beresiko \\
4 & Ekonomi Orang Tua & 0,000 & 13,600 & Beresiko \\
5 & Pekerjaan Orang Tua & 0,766 & 0,700 & Tidak Beresiko \\
6 & Personal Hygene & 0,136 & 3,025 & Tidak Beresiko \\
7 & Kontak Serumah & 0,000 & 35,714 & Beresiko \\
& & & & \\
\hline
\end{tabular}


Tabel 4.17. Hasil Analisis dengan Korelasi Spearmen

\begin{tabular}{|l|l|c|c|c|c|}
\hline No & \multicolumn{1}{|c|}{ Variabel Bebas } & $\begin{array}{c}\text { P Value Uji } \\
\text { Korelasi }\end{array}$ & $\begin{array}{c}\text { Nilai r } \\
\text { Koefesien } \\
\text { Relasi }\end{array}$ & $\begin{array}{c}\text { Tingkat } \\
\text { Hubungan Nilai } \\
\text { r }\end{array}$ & Keterangan \\
\hline 1 & Jenis Kelamin & 0,934 & 0,11 & Sangat Lemah & Tidak Ada Hubungan \\
2 & Umur & 0,449 & 0,105 & Sangat Lemah & Tidak Ada Hubungan \\
3 & Pendidikan orang Tua & 0,522 & 0,089 & Sangat Lemah & Tidak Ada Hubungan \\
4 & Ekonomi Orang Tua & 0,000 & 0,509 & Sedang & Ada Hubungan \\
5 & Pekerjaan Orang Tua & 0,449 & 0,105 & Sangat Lemah & Tidak Ada Hubungan \\
6 & Personal Hygene & 0,027 & 0,301 & Lemah & Tidak Ada Hubungan \\
7 & Kontak Serumah & 0,000 & 0,724 & Kuat & Ada Hubungan \\
\hline
\end{tabular}




\section{PEMBAHASAN}

\section{Hubungan antara jenis kelamin dengan kejadian kusta}

Hasil uji chi-square diperoleh

nilai $p(1,000)>\operatorname{sig}(0,05)$ sehingga Ho diterima. Hal ini berarti dapat diketahui bahwa tidak ada hubungan antara jenis kelamin dengan kejadian kusta. Nilai odd ratio $(\mathrm{OR})=1,176$ (>1 = bersifat resiko) hal ini berarti bahwa responden dengan jenis kelamin laki-laki memiliki resiko 1,176 kali untuk terkena penyakit kusta dibandingkan dengan responden berjenis kelamin perempuan.

Perbedaan jenis kelamin terhadap timbulnya penyakit kusta belum dapat dipastikan, pada dasarnya penyakit kusta dapat menyerang semua orang, namun laki-laki lebih banyak terkena dibandingkan dengan wanita, dengan perbandingan 2:1, walaupun ada beberapa daerah yang menunjukkan penderita wanita lebih banyak ${ }^{8}$.

Menurut hasil penelitian Sri Poedji Hatoety tahun 1996, bahwa penderita kusta lebih banyak terjadi pada laki-laki yaitu sebanyak 70,5\% sedangkan pada perempuan terdapat 29,5\%. Hasil penelitian ini mendukung peneliti sebelumnya Louhennpessy tahun 1985, yang menyatakan bahwa perbandingan penderita kusta laki-laki dan perempuan adalah 2,3:1,0, artinya penderita kusta pada laki-laki 2,3 kali lebih banyak daripada perempuan. Relatif rendahnya kejadian kusta pada perempuan kemungkinan karena faktor lingkungan atau faktor biologi. Seperti penyakit menular lain, lakilaki banyak terpapar dengan faktor risiko sebagai akibat dari gaya hidupnya ${ }^{2}$.

Hasil penelitian ini sesuai dengan pendapat dari Marwali Harahap (2000: 261) yang menyatakan bahwa penyakit kusta dapat menyerang semua orang. Lakilaki lebih banyak terkena dibandingkan dengan wanita dengan perbandingan 2:1. Walaupun ada beberapa daerah yang menunjukkan insidens ini hampir sama bahkan ada daerah yang menunjukkan penderita wanita lebih banyak. Begitu juga seperti yang ada dalam Depkes RI, (2007: 8) bahwa laki-laki lebih banyak terserang dari pada wanita. Relatif rendahnya kejadian kusta pada perempuan kemungkinan karena faktor lingkungan atau faktor biologi. Seperti kebanyakan penyakit menular lainnya laki-laki lebih banyak terpapar dengan faktor risiko sebagai akibat gaya hidupnya

2. Hubungan antara umur dengan kejadian kusta

Hasil uji chi-square diperoleh nilai $p(0,788)>\operatorname{sig}(0,05)$ sehingga Ho diterima. Hal ini berarti dapat diketahui bahwa tidak ada hubungan antara umur dengan kejadian kusta. Nilai odd ratio $(\mathrm{OR})=1,375(>1=$ bersifat resiko) hal ini berarti bahwa responden dengan umur 5-9 tahun 
memiliki resiko 1,375 kali untuk terkena penyakit kusta dibandingkan dengan responden umur 10-14 tahun.

Kejadian suatu penyakit sering terkait pada umur. Pada penyakit kronik seperti kusta diketahui terjadi pada semua umur, berkisar antara bayi sampai umur tua (3 minggu sampai lebih dewasa lebih dari 70 tahun). Namun yang terbanyak adalah pada umur muda dan produktif ${ }^{2}$. Pada dasarnya kusta dapat menyerang semua umur, anakanak lebih rentan dari orang dewasa. Frekuensi tertinggi pada orang dewasa ialah umur 25- 35 tahun, sedangkan pada kelompok anak umur 10-12 tahun.

Hasil penelitian ini sesuai dengan hasil penelitian dari Maria Christiana (2008) di Kabupaten Jepara yang menyatakan tidak ada hubungan antara umur risiko dengan kejadian kusta. Begitu juga dengan hasil penelitian Puspita Kartika Sari (2005) di Pemalang yang menyatakan tidak ada hubungan antara umur risiko dengan kejadian kusta dan hasil penelitian Yessita Yuniarasari (2013) di Kabupaten Rembang juga tidak menemukan adanya hubungan antara umur dengan kejadian kusta.

\section{Hubungan antara pendidikan dengan kejadian kusta}

Hasil uji chi-square diperoleh nilai $p(0,569)>\operatorname{sig}(0,05)$ sehingga Ho diterima. Hal ini berarti dapat diketahui bahwa tidak ada hubungan antara pendidikan orang tua dengan kejadian kusta. Nilai odd ratio (OR) $=1,633(>1$ = bersifat resiko) hal ini berarti bahwa responden dengan pendidikan orang tua SD,SMP memiliki resiko 1,633 kali untuk terkena penyakit kusta dibandingkan dengan responden dengan pendidikan orang tua SMA,PT.

Brakel dan Kaur mengemukakan bahwa dari 20 penderita kusta terdapat $65 \%$ penderita tidak menempuh pendidikan formal, sedang yang menyelesaikan pendidikan formal $5 \%$. Analisis spasial yang dilakukan oleh Winarsih di Kabupaten Jepara menunjukkan bahwa faktor risiko yang berhubungan dengan penyakit kusta yaitu pendidikan dengan persentase sebesar 88,1\%.10 Berdasarkan hasil analisis diperoleh nilai $\mathrm{OR}=11,018$ (95\% CI 5,52521,970). Hal ini berarti tingkat pendidikan merupakan faktor risiko yang bermakna terhadap kejadian penyakit kusta. Responden dengan tingkat pendidikan rendah $(\leq$ tamat SMP). Perlunya ditanamkan kesadaran tentang pendidikan umum dan kesehatan pada usia dini, sehingga dapat menciptakan penerus yang berpendidikan dan sehat. Penelitian Saktiarni di Kediri menyatakan bahwa tingkat pendidikan rendah akan meningkatkan risiko 6,08 kali lebih besar tidak patuh berobat dibandingkan dengan tingkat pendidikan tinggi $(\mathrm{OR}=6,08 ; 95 \% \mathrm{CI}$ $1,46-29,13$ ) 
Hasil penelitian ini yaitu penderita kusta lebih banyak yang memiliki tingkat pendidikan rendah. Pendidikan yang rendah oleh penderita sebagai salah satu faktor yang berhubungan dengan kejadian kusta karena seperti yang diungkapkan oleh Soekidjo Notoatmodjo (2005: 26) dan Budioro (1997:113) bahwa tingkat pendidikan dianggap sebagai salah satu unsur yang menentukan pengalaman dan pengetahuan seseorang, baik dalam ilmu pengetahuan maupun kehidupan sosial.

Bahasa yang sesuai dengan tingkat pendidikan akan lebih memudahkan masyarakat untuk memahami isi dari pesan yang disampaikan oleh penyuluh, sehingga diharapkan masyarakat dengan tingkat pendidikan rendah juga memiliki pengetahuan yang baik tentang penyakit kusta, dengan pengetahuan yang baik tentang kesehatan termasuk penyakit menular, seperti halnya kusta, masyarakat dapat secara aktif turut mencegah terjadinya penyakit menular.

\section{Hubungan antara ekonomi dengan kejadian kusta}

Hasil uji chi-square diperoleh nilai $p(0,000)<\operatorname{sig}(0,05)$ sehingga Ho ditolak. Hal ini berarti dapat diketahui bahwa ada hubungan antara ekonomi orang tua dengan kejadian kusta. Nilai odd ratio (OR) $=13,600(>1=$ bersifat resiko $)$ hal ini berarti bahwa responden dengan status ekonomi orang tua < UMP Sorong memiliki resiko 13,600 kali untuk terkena penyakit kusta dibandingkan dengan responden dengan status ekonomi orang tua $\geq$ UMP Sorong.

Hasil penelitian menunjukkan bahwa ada hubungan antara status social ekonomi dengan kejadian kustadi wilayah kerja puskesmas Kunduran, Blora. Hasil ini didasarkan pada uji Chi-square, diperoleh nilai $\mathrm{p}(0,000)<\alpha(0,05)$. Nilai odd ratio sebesar 6,296 dan 95\% CI $(2,380-20,157)$ sehingga dapat diketahui bahwa responden yang memiliki status sosial ekonomi rendah memiliki risiko 6,296 kali lebih besar mengalami kejadian kusta dibandingkan responden yang memiliki status sosial ekonomi tinggi Hasil penelitian Dwi Ningrum, dkk (2013) di Kota Makassar diketahui bahwa sebagian besar penderita kusta adalah dari golongan ekonomi rendah. Keadaan sosial ekonomi lemah dapat menjadi faktor yang memperburuk perkembangan kusta. Status ekonomi merupakan faktor risiko yang bermakna terhadap kejadian penyakit kusta. Responden dengan status ekonomi rendah memiliki risiko 41,889 kali besar untuk menderita penyakit kusta dibandingkan responden dengan status ekonomi tinggi. Hasil penelitian ini sejalan dengan penelitian yang dilakukan oleh Eliningsih di Kabupaten Tegal 
dan Christiana di Jepara menunjukkan bahwa status ekonomi bermakna secara statistik dengan kejadian penyakit kusta.

Faktor ekonomi turut mempengaruhi kebutuhan hidup, termasuk kebutuhan makanan dan kesehatan. Jika kebutuhan akan makanan sehat tidak terpenuhi maka dapat melemahkan daya tahan tubuh, sehingga mudah terserang suatu penyakit seandainya mendapat penularan (Indan Entjang, 2000:24). Seseorang kurang memanfaatkan pelayanan kesehatan yang ada mungkin oleh karena tidak cukup uang untuk membeli obat, membayar transport dan sebagainya (Bambang Sutrisna, 1994:14), hal ini sesuai dengan pendapat Arif Mansjoer (2000:65) yang menyatakan bahwa timbulnya penyakit kusta pada seseorang tidak mudah sehingga tidak perlu ditakuti. Hal ini tergantung pada beberapa faktor, antara lain sosial ekonomi.

Sudah diketahui bahwa faktor sosial ekonomi sangat berperan penting dalam kejadian kusta. Hal ini terbukti pada negara-negara di Eropa dengan adanya peningkatan sosial ekonomi, maka kejadian kusta akan cepat menurun bahkan hilang. Kasus kusta impor pada negara tersebut ternyata tidak menularkan pada orang yang tingkat sosial ekonominya tinggi. Kegagalan kasus kusta impor untuk menularkan pada kasus kedua di Eropa juga disebabkan karena tingkat sosial ekonomi yang tinggi (Depkes RI, 2006:8). Jadi jelas bahwa status sosial ekonomi memberikan pengaruh yang cukup besar terhadap terjadinya penyakit kusta.

\section{Hubungan antara pekerjaan orang tua dengan kejadian kusta}

Hasil uji chi-square diperoleh nilai $p(0,766)>\operatorname{sig}(0,05)$ sehingga Ho diterima. Hal ini berarti dapat diketahui bahwa tidak ada hubungan antara pekerjaan orang tua dengan kejadian kusta. Nilai odd ratio (OR) $=0,700(<1=$ bersifat protektif $)$ hal ini berarti pekerjaan orang tua tidak terlalu beresiko dengan kejadian kusta.

Jenis pekerjaan disini yaitu pekerjaan atau mata pencaharian sehari-hari yang dilakukan responden, digolongkan menjadi pekerjaan ringan (tidak bekerja, pelajar, pegawai kantor) dan pekerjaan berat (pekerja bangunan, buruh, tukang batu, pekerja bengkel, penjahit, buruh angkut, pembantu, petani dan nelayan).

Berdasarkan penelitian yang dilakukan oleh Nur Laily Af'idah (2012) tentang analisis faktor risiko kejadian kusta di Kabupaten Brebes tahun 2010, prosentase jenis pekerjaan yang berisiko kusta sebesar $85,5 \%$ dan yang tidak berisiko sebesar $14,5 \%$. Uji statistik menunjukkan bahwa ada hubungan antara jenis pekerjaan dengan kejadian kusta.

Hal ini selaras dengan penelitian Joko Kurnianto (2002), 
yang menyatakan penderita dengan pekerjaan berat $(66,7 \%)$ lebih rentan daripada penderita dengan pekerjaan ringan $(33,8 \%)$. Pekerjaan dapat digunakan untuk menganalisis adanya kemungkinan risiko timbulnya penyakit.

\section{Hubungan antara personal hygene dengan kejadian kusta}

Hasil uji chi-square diperoleh nilai $p(0,136)>\operatorname{sig}(0,05)$ sehingga Ho diterima. Hal ini berarti dapat diketahui bahwa tidak ada hubungan antara personal hygene dengan kejadian kusta. Nilai odd ratio (OR) $=3,025$ ( $>1=$ bersifat resiko) hal ini berarti bahwa responden dengan personal hygiene buruk memiliki resiko 3,025 kali untuk terkena penyakit kusta dibandingkan dengan responden dengan personal hygiene baik.

Hasil penelitian Indriani, dkk (2014) di Wilayah kerja Puskesmas Kunduran, Blora.menunjukkan bahwa ada hubungan antara personal hygiene dengan kejadian kusta. Disimpulkan bahwa responden yang memiliki personal hygiene buruk belum tentu merupakan faktor risiko penyakit kusta.

(2013) $\begin{array}{r}\text { Penelitian Yessita } \\ \text { menyimpulkan }\end{array}$ responden yang memiliki personal hygiene buruk mempunyai risiko 5,333 kali lebih besar terkena kusta daripada responden yang memiliki personal hygiene baik. Hal ini menunjukkan personal hygiene faktor risiko yang berhubungan kejadian kusta.

Hubungan Personal Hygiene dengan Kejadian Kusta Personal Hygiene diketahui bahwa dari kelompok kasus tidak memenuhi syarat, menderita kusta sebesar $73,7 \%$ sedangkan pada kontrol $39,5 \%$. Hasil uji statistik diperoleh nilai $\mathrm{p}=0,005$, yang berarti disimpulkan ada hubungan yang bermakna antara personal hygiene dengan kejadian kusta di Kabupaten Lampung Utara Tahun 2014-2016. Hasil penelitian sejalan dengan Setiani (2014), bahwa ada hubungan personal hygiene dengan kejadian Kusta dengan hasil $(\mathrm{p}=0,001)$. Hal ini sejalan Indriani (2014).

Hasil penelitian Nisa Amira, dkk (2016) menunjukkan bahwa terdapat hubungan antara kebersihan badan dan rambut dengan kejadian kusta anak di Kabupaten Pasuruan tahun 2014-2015. Anak yang memiliki kebersihan badan dan rambut yang kurang baik lima kali lebih berisiko tertular kusta daripada anak yang memiliki kebersihan badan dan rambut yang baik.

Kebiasaan menggunakan alat-alat pribadi (handuk, sabun, sisir) bersama dapat menjadi salah satu media penularan penyakit kusta sesuai dengan teori yang dikemukakan oleh Arif Mansjoer (2000:65), menyatakan bahwa kuman kusta dapat mencapai permukaan kulit melalui folikel rambut dan kelenjar keringat. 
7. Hubungan antara ada riwayat kontak dengan kejadian kusta

Hasil uji chi-square diperoleh nilai $p(0,000)<\operatorname{sig}(0,05)$ sehingga Ho ditolak. Hal ini berarti dapat diketahui bahwa ada hubungan antara ada riwayat kontak dengan kejadian kusta. Nilai odd ratio (OR) $=35,714$ (> 1 = bersifat resiko) hal ini berarti bahwa responden dengan ada riwayat kontak serumah memiliki resiko 35,714 kali untuk terkena penyakit kusta dibandingkan dengan responden dengan tidak ada riwayat kontak serumah.

Risiko orang dengan riwayat kontak serumah untuk tertular penyakit kusta sebesar 15,127 kali lebih besar dibandingkan dengan tidak ada riwayat kontak serumah dan bermakna secara signifikan. Riwayat kontak adalah riwayat seseorang yang berhubungan dengan penderita kusta baik serumah maupun tidak serumah. Sumber penularan kusta adalah kusta utuh yang berasal dari penderita kusta, jadi penularan kusta lebih mudah terjadi jika ada kontak langsung dengan penderita kusta ${ }^{13}$. Berdasarkan hasil uji statistik didapat OR yaitu 15,127 pada CI $95 \% 4,572$ - 50,056, artinya risiko orang dengan riwayat kontak serumah untuk tertular penyakit kusta sebesar 15,127 kali lebih besar dibandingkan dengan tidak ada riwayat kontak serumah dan bermakna secara signifikan.
Meskipun belum diketahui secara pasti tentang bagaimana cara penularan penyakit kusta, namun secara teoritis penularan ini dapat terjadi secara kontak yang lama dengan penderita baik serumah maupun tidak serumah (Depkes RI 2006:10).

Riwayat kontak bisa menularkan berbagai macam penyakit. Penularan kontak bisa langsung (direct contac) dan tidak langsung (indirect contac). Kontak langsung dapat terjadi melalui hubungan fisik langsung seperti pada berbagai macam penyakit kelamin (veneral disease), penyakit kulit (seperti kusta), penyakit mata dan lain-lain.

Secara teoritis penularan ini dapat terjadi dengan kontak yang erat dan lama dengan penderita, namun penderita dengan kusta tipe basah atau multibasiler, tetapi penularan ini juga dipengaruhi oleh daya tahan tubuh seseorang. Meskipun lama kontak kurang dari dua tahun, tetapi jika seseorang memiliki riwayat kontak yang tinggi dengan penderita kusta yang belum diobati, maka akan menyebabkan penularan penyakit kusta yang relatif singkat, karena penyakit kusta yang tidak minum obat sesuai dengan regimen WHO, merupakan sumber penularan bagi orang lain. 


\section{Keterbatasan Penelitian}

Keterbatasan dalam penelitian ini antara lain :

a) Peneliti hanya menggunakan control sedikit $1: 1$ dikarenakan keterbatasan biaya, waktu, dan tenaga dalam pengambilan data

b) Sebagian responden hanya dapat ditemui pada jam-jam tertentu saja sehingga peneliti menyesuaikan waktu berkunjung

\section{Kelemahan Penelitian}

a. Pada variabel lama kontak hanya dilakukan penelitian terhadap anggota keluarga responden yang didiagnosa menderita kusta. Hal tersebut tidak menutup kemungkinan tetangga sekitar responden yang juga terdiagnosa kusta terutama tipe multibasiler yang belum mendapatkan pengobatan dapat menjadi sumber penularan penyakit.

b. Responden ada beberapa yang malu ketika bertemu petugas disebabkan penyakit ini masih terpersepsi dimasyarakat sebagai penyakit kutukan sehingga dibutuhkan pendekatan emosional.

\section{E. KESIMPULAN}

Berdasrkan hasil penelitian dapat disimpulkan sebagai berikut :

1. Ada resiko antara ekonomi orang tua dan ada riwayat kontak serumah dengan kejadian kusta diwilayah kota sorong pada anak umur 5-14 tahun
2. Tidak ada resiko antara jenis kelamin, umur, pendidikan orang tua, pekerjaan orang tua, personal hygene dengan kejadian kusta diwilayah kota sorong pada anak umur 5-14 tahun

\section{F. DAFTAR PUSTAKA}

1. Depkes RI, 2005. Epidemiologi dan Program.

2. Departemen Kesehatan Republik Indonesia, 2006, Buku Pedoman Pemberantasan Penyakit Kusta. Cetakan XV, Jakarta: Dirjen PPM dan PL.

3. Sasakawa Memorial Health Foundation, Atlas Kusta, 2004 ; 1-3.

4. Kementrian Kesehatan RI. Profil Kesehatan Indonesia 2010. Jakarta: Kementrian Kesehatan RI; 2011.

5. Amirudin, MD. Penyakit Kusta Sebuah Pendekatan Klinis. Makassar: Brilian International; 2012.

6. Depkes RI, 2005, Buku Pedoman Nasional Pemberantasan Penyakit Kusta, Edisi 17, Jakarta:Depkes RI.

7. Depkes RI, 2007, Rencana Aksi Nasional Pengendalian Kusta.

8. Amiruddin Dali, 2012. Penyakit Kusta Sebuah Pendekatan Klinis. Brilian International Sidoarjo 
9. Depkes RI, 2016. Profil Kesehatan Indonesia Tahun 2015.

10. Depkes RI, 2015. Profil Kesehatan Indonesia Tahun 2014.

11. Depkes RI, 2006. Buku Pedoman Kusta Nasional untuk pelaksanaan pemberantasan kusta di daerah endemik Rendah. Edisi 18. Jakarta.

12. Silvia Indriani, 2014. Faktor-Faktor Yang Berhubungan Dengan Kejadian Kusta. UNNES Semarang.

13. B. K. Mandal, 2006, Penyakit Infeksi, Terjemahan oleh Jualita Surapsi. Jakarta : Erlangga.

14. Sugiono. Metode Penelitian Administrasi Metode $R \& D$. Alfabeta Bandung, 2012

15. Riduwan. Variabel-Variabel Penelitian. Alfabeta Bandung, 2007.

16. Notoatmodjo S. Metodologi Penelitian Kesehatan. Rineka Cipta Jakarta, 2010.

17. Hastono. Sutanto P. Analisis Data Kesehatan. FKM UI, 2007.

18. Sarjono H \& Julianita W. SPSS vs LISREL. Salembah Empat Jakarta, 2011.

19. James Chin, 2006, Manual Pemberantasan Penyakit Menular, Jakarta:CV. Infomedika

Healthy Series.

21. Nur Nasry Noor, 2006, Pengantar Epidemiologi Penyakit Menular, Jakarta:Rineka Cipta.

22. Wayne M.Meyers, 2000, Hunter'S Tropical Medicine and Emerging Infectious

Disease, Philadhelpia:W.B Saunders Company.

23. Kosasih A, Made Wisnu I, Emmy S.J, Linuwih S.M, Kusta dalam Andhi Juanda. 2005. Ilmu Penyakit Kulit dan Kelamin. Edisi IV. Jakarta: FKUI.

24. Maria Christiana, 2008, Analisis Faktor Risiko Kejadian Kusta (Studi Kasus di Rumah Sakit Kusta Donorejo Jepara) Tahun 2008. Skripsi : Universitas Negeri Semarang.

25. Marwali Harahap, 2000, Ilmu Penyakit Kulit, Jakarta : Hipokrates.

26. Muh. Dali Amiruddin. 2012. Penyakit Kusta Sebuah Pendekatan Klinis. Sidoarjo: Penerbit Brilian Internasional.

27. Risha Andri Saputri, 2009, FaktorFaktor yang Berhubungan dengan Kejadian

Cacat Tingkat 2 Pada Penderita 
Kusta. Skripsi : Universitas Negeri Semarang

28. Robin Graham, 2005, Dermatologi, Jakarta : Erlangga.

29. Adhi Djuanda, 2007, Ilmu Penyakit Kulit dan Kelamin, Jakarta : FKUI.

30. Robin Graham, 2005, Dermatologi, Jakarta : Erlangga. 